\title{
Wild chinook salmon survive better than hatchery salmon in a period of poor production
}

\author{
R. J. Beamish • R. M. Sweeting • C. M. Neville • \\ K. L. Lange $\cdot$ T. D. Beacham $\cdot$ D. Preikshot
}

Received: 21 August 2010/Accepted: 8 March 2011 /Published online: 6 April 2011

(C) The Author(s) 2011. This article is published with open access at Springerlink.com

\begin{abstract}
The population dynamics of chinook salmon (Oncorhynchus tshawytscha) from the Cowichan River on Vancouver Island, British Columbia, Canada are used by the Pacific Salmon Commission as an index of the general state of chinook salmon coast wide. In recent years the production declined to very low levels despite the use of a hatchery that was intended to increase production by improving the number of smolts entering the ocean. In 2008, we carried out an extensive study of the early marine survival of the hatchery and wild juvenile chinook salmon. We found that both rearing types mostly remained within the Gulf Islands study area during the period when most of the marine mortality occurred for the hatchery fish. By mid September, approximately $1.3 \%$ of all hatchery fish survived, compared to $7.8 \%-31.5 \%$ for wild fish. This six to 24 times difference in survival could negate an estimated increased egg-to-smolt survival of about $13 \%$ that is theorized to result through the use of a hatchery. Estimates of the early marine survival are approximate, but sufficient to show a dramatic difference in the response of the two rearing types to the marine nursery area. If the declining trend in production continues for both rearing types, modifications to the hatchery program are needed to improve survival or an emphasis
\end{abstract}

R. J. Beamish $(\bowtie) \cdot$ R. M. Sweeting $\cdot$ C. M. Neville

K. L. Lange · T. D. Beacham • D. Preikshot

Fisheries \& Oceans Canada, Pacific Biological Station,

3190 Hammond Bay Road,

Nanaimo, BC V9T 6N7, Canada

e-mail: Richard.Beamish@dfo-mpo.gc.ca on improving the abundances of wild stocks is necessary, or both. The discovery that the juvenile Cowichan River chinook salmon remain within a relatively confined area of the Gulf Islands within the Strait of Georgia offers an excellent opportunity to research the mechanisms that cause the early marine mortalities and hopefully contribute to a management that improves the production.

Keywords Chinook salmon · Salmon hatchery · Early marine survival $\cdot$ Strait of Georgia

\section{Introduction}

The Strait of Georgia, located between Vancouver Island and the British Columbia mainland is a major nursery area for Pacific salmon (Oncorhynchus spp., Fig. 1). Historically, about $35 \%$ to $40 \%$ of the commercial and recreational catch of Pacific salmon in British Columbia reared as juveniles in the Strait of Georgia (Beamish and Neville 1999). The Strait of Georgia ecosystem is changing, as indicated by an increasing temperature of about $1{ }^{\circ} \mathrm{C}$ in the past 50 years (Fig. 2) and by the changing composition of the major species of Pacific salmon. In recent years, the marine survival of coho (O. kisutch) and chinook (O. tshawytscha) salmon dropped to the lowest levels in recorded history (Beamish et al. 1995, 2008, 2010; Beamish and Neville 1999) while the abundances of pink (O. gorbuscha) and chum (O. keta) salmon are close to historic high levels 


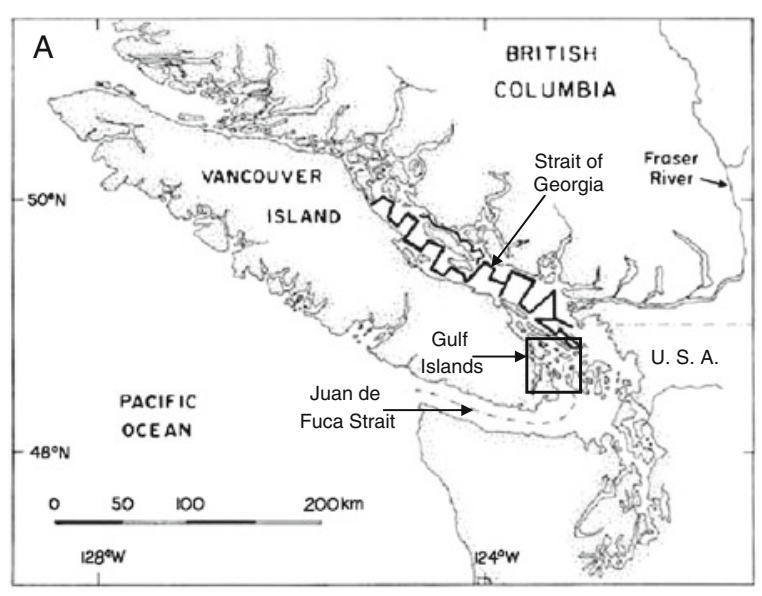

Fig. 1 Standard track lines (solid lines) for trawl surveys in the Strait of Georgia. Sets were evenly spaced along the track lines. Black box shows location of the Gulf Islands

(Beamish and Neville 1999; Beamish et al. 2007). Sockeye salmon (O. nerka) returns to the Fraser River drainage declined since about 1994 and in 2009 were the lowest ever recorded. These reasons for the recent poor returns are being investigated by a Judicial Inquiry (http://www.commissioncohen.ca/en/).

In the mid 1980s, Canada initiated a cooperative program with the United States to reverse the decline of chinook salmon abundance (PSC 1987). All of the reasons for the decline were not understood, but it was apparent that fishing had an important impact. The management of fishing required international cooperation with the United States and this was accomplished through the International Pacific Salmon Commission (PSC 1987). Chinook salmon from the Cowichan River were selected as a population that could be used as an indicator of the health of chinook salmon in general and the ability of the program to increase the abundance of chinook salmon in particular. In 2000 , the escapement target was recommended to be 7400 (95\% confidence intervals: 4185-18 915; Riddell et al. 2000). More recent escapement goals were estimated to be 6500 and 6600 (Tompkins et al. 2005; Parken et al. 2006). Escapements increased in the early 1990s and generally exceeded the recommended target (Fig. 3). However, beginning in the late 1990 s, escapements declined to the very low abundance of 981 in 2008. The escapement estimates do not include chinook salmon that are removed from the river for brood stock for the hatchery. In 2008 and 2009, the hatchery brood stock was 667 and 612 fish, respectively. Part of the reason for the recent decline in escapement is the declining marine survival (Fig. 4). This decline in survival is likely related to ecosystem changes within the Strait of Georgia (Hinke et al. 2005; Beamish et al. 2008, 2010; Beauchamp 2009).

In the late 1970s, the Department of Fisheries and Oceans Canada established a program to use hatcheries to increase the abundances of coho and chinook salmon (Fisheries and Environment Canada 1978). The basis for the program was a belief that there was additional capacity within the Strait of Georgia to produce more Pacific salmon and that hatcheries could add more fish to the ocean faster than could be added through a managed natural production. A hatchery along the Cowichan River started to produce chinook salmon in 1979 using adults returning to the Cowichan River (Cross et al. 1991). The number of adults removed from the population ranged from 175 to 678 up to 1990 (Fig. 5). Beginning in 1991, the number of adults removed from the spawning population to produce juveniles increased to an average of 1235 between 1991 and 2008. In recent years, the number of juveniles released from the hatchery into the river averaged 1.9 million from 2000 to 2009 and ranged from 3.2 million to 0.5 million (Fig. 6). The hatchery on the Cowichan River has not only been unable to increase the abundance, it has also not been able to sustain the abundances that existed at the time the program started.

In this paper we report the results of an intensive study to compare the early marine survival of hatchery and wild chinook salmon from the Cowichan River in the Strait of Georgia. This report is restricted to 2008 because all fish released from the hatchery in this year could be readily identified as they received a coded wire tag (CWT) and had the adipose fin clipped. We consider that all naturally spawning fish are wild. We use this terminology only for consistency and do not consider that our use is the correct definition of a wild Pacific salmon.

\section{Methods}

The trawl survey methodology and trawl net design are reported in Beamish et al. (2000) and Sweeting et al. (2003). The set locations within the Gulf Islands, Strait of Georgia and Juan de Fuca Strait are shown in Fig. 7. Each set was approximately $30 \mathrm{~min}$ in length 
Fig. 2 Average sea surface temperatures from lighthouses in the Strait of Georgia from 1960 to 2010 for a) winter (December to March) and b) Spring (April to June)
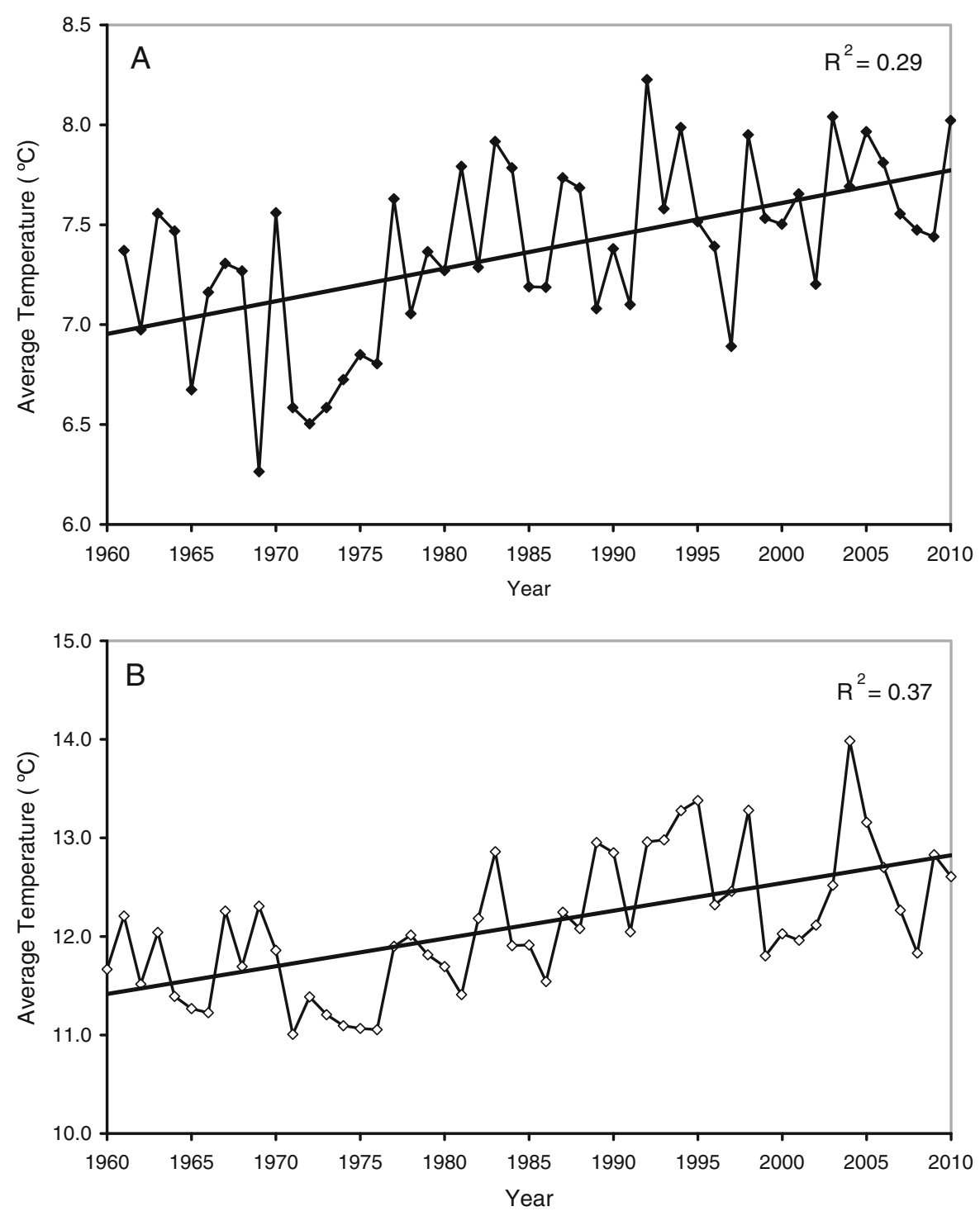

and fished an average of about $4.3 \mathrm{~km}$. Catch per unit effort (CPUE) is the catch expanded to one hour. Most sets were at the surface, but sets were made with the head rope at 14 and $29 \mathrm{~m}$ in the Gulf Islands and deeper sets were included in the surveys in the Strait of Georgia. Abundance was determined using the procedures in Beamish et al. (2000) and modified in Beamish et al. (2008). The procedures for the stratum volumes are in Thomson and Foreman (1998). In the Gulf Islands, we estimated a volume of $9.3 \mathrm{~km}^{3}$ for the strata $0-14 \mathrm{~m}, 15-29 \mathrm{~m}$ and $30-44 \mathrm{~m}$. The area is relatively shallow compared of the open Strait of Georgia with about 35\% deeper than $45 \mathrm{~m}$. The total volume of water fished in each stratum was divided

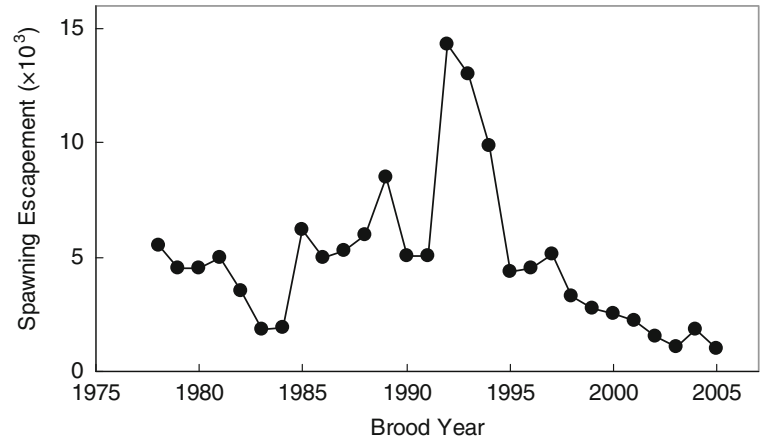

Fig. 3 Spawning escapement of chinook salmon in the Cowichan River, for brood years 1978-2008 or ocean entry year 1979-2009 and return year 1982-2012. Data from Tompkins et al. (2005) and the Department of Fisheries and Oceans (www.pac.dfo-mpo.gc.ca/gis-sig/maps-cartes-eng.htm) 


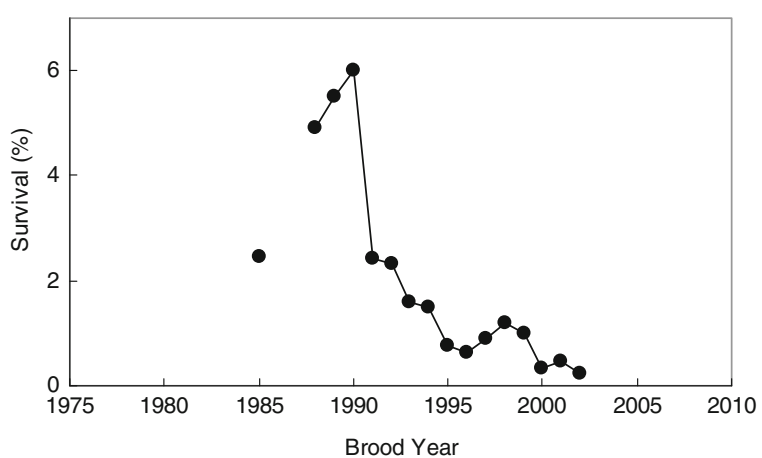

Fig. 4 Marine survival of Cowichan River chinook salmon, by brood year 1985-2002, or ocean entry year 1986-2003 and return year 1989-2006, using coded wire tag (CWT) information from hatchery fish, reported in Tompkins et al. (2005). Note that there were no data for 1986 and 1987

into the total volume of water in the particular $15 \mathrm{~m}$ layer to estimate the percentage of water fished. An assumption in the calculation was that the catchability of fish by the net was 1.0 (Beamish et al. 2000). If the catchability was less than 1.0, actual abundance would be underestimated. Catches of juvenile chinook salmon in the standard trawl surveys in the Strait of Georgia (Beamish et al. 2008, 2010) were used to show that juvenile chinook salmon originating from the Cowichan River were rarely found in the Strait of Georgia in July and September.

A purse seine survey was conducted within the Gulf Islands area from June 20-27, 2008. The $38 \mathrm{ft}$ $(11.7 \mathrm{~m})$ vessel fished a $420 \mathrm{ft}(129.2 \mathrm{~m})$ purse seine that was $60 \mathrm{ft}(18.5 \mathrm{~m})$ deep and had $1 / 4$ inch $(6 \mathrm{~mm})$ mesh in the bunt. Approximately 10 sets were

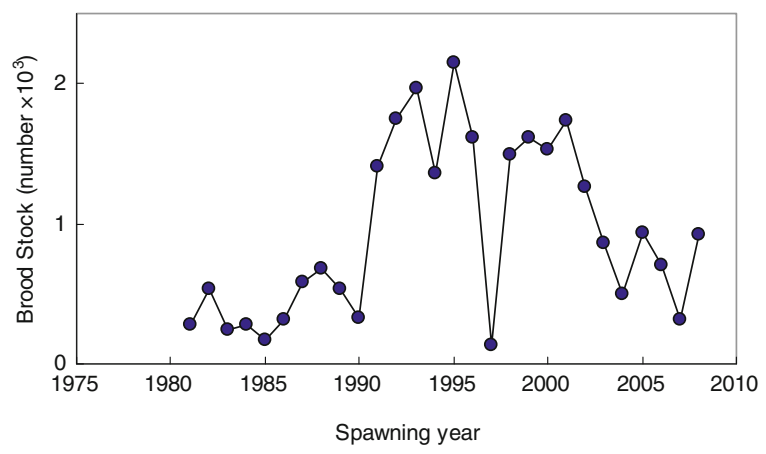

Fig. 5 Number of chinook salmon in the Cowichan River used as hatchery brood stock, 1981-2008. Data are from Tompkins et al. (2005) and the Department of Fisheries and Oceans (www.pac.dfo-mpo.gc.ca/gis-sig/maps-cartes-eng.htm)

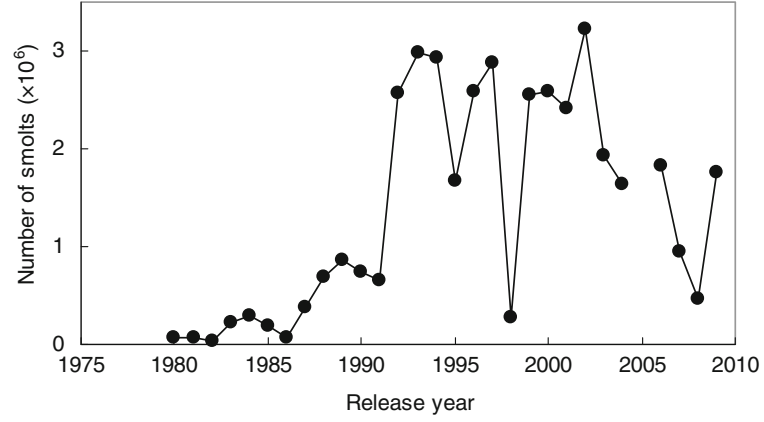

Fig. 6 Numbers of smolts released by Cowichan River Hatchery, by release year 1980-2009. Data are from the Department of Fisheries and Oceans (www.pac.dfo-mpo.gc.ca/ gis-sig/maps-cartes-eng.htm). Note that there were no data for 2005.

completed each day, with sets spaced throughout the Gulf Islands, including Cowichan Bay (Fig. 7b, d). All fish were identified and up to 50 juvenile chinook salmon per set were measured for fork length and checked for the presence of a CWT. Otolith and scale samples were taken from up to 10 fish per set. A sample of the operculum was taken for DNA analysis and preserved in $95 \%$ ethanol.

A beach seine survey was carried out from April 8 to June 6 in the Cowichan River estuary (Cowichan Bay). Approximately seven sets were made each day, two times a week. Two teams fished concurrently on the north and south side of Cowichan Bay. The marking of all hatchery fish with a clipped adipose fine facilitated the recognition of hatchery and wild juvenile chinook salmon. All species of Pacific salmon were examined, but only the catches and lengths of chinook salmon are reported here.

Fish were sampled for DNA using pieces of the operculum preserved in $95 \%$ ethanol or dried material from around the otolith. Up to 50 fish were sampled from each set and the resulting samples were analyzed for stock composition using the procedures described in Beacham et al. (2006). Briefly summarized, 12 microsatellites (Ots 102 not included) were analyzed for all individuals in the samples. A baseline of 280 populations ranging from the Alsek River in northern British Columbia to the Sacramento River in California was used as the basis for estimating stock composition of mixed-stock samples with cBayes (Neaves et al. 2005). In the analysis, ten 20 000-iteration Monte Carlo Markov chains of estimated stock compositions were produced, with initial starting values for each 

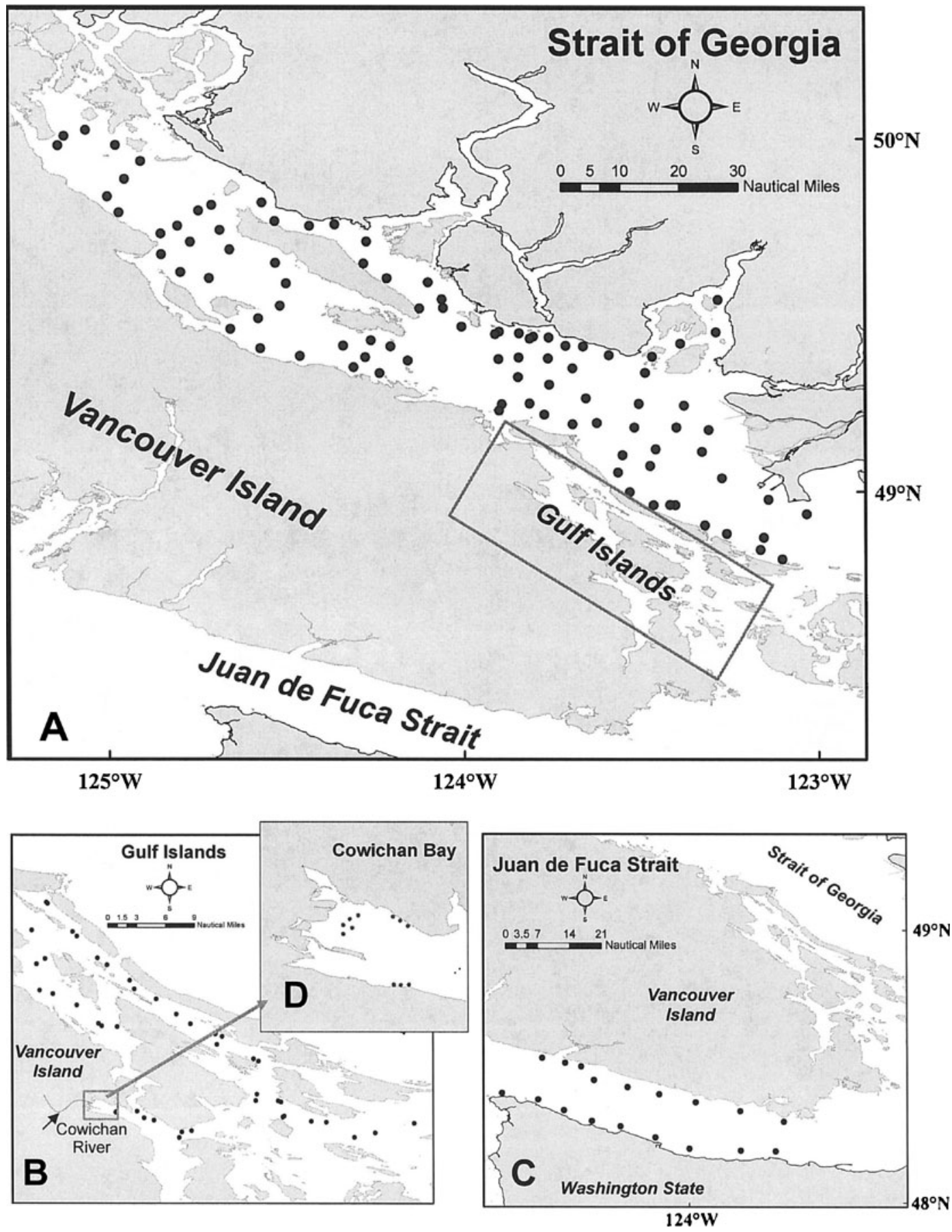

Fig. 7 Survey and set locations for (a) Strait of Georgia (b) Gulf Islands (c) Juan de Fuca Strait and (d) Cowichan Bay. Black dots indicate the locations of sets

chain set at 0.90 for a particular population that was different for each chain. Estimate stock compositions were considered to have converged when the shrink factor was $<1.2$ for the 10 chains (Pella and Masuda 2001). The last 1000 iterations from each of the 10 chains were then combined and for each fish the 
probability of originating from each population in the baseline was determined. These individual probabilities were summed over all fish in the sample and divided by the number of fish sampled to provide the point estimate of stock composition. Standard deviations of estimated stock compositions were determined from the last 1000 iterations from each of the 10 chains incorporated in the analysis. The accuracy of the stock compositions was examined by comparing the determinations to known stock compositions using CWTs. We used all samples from the July and September trawl surveys in the Strait of Georgia from 2007, 2008 and 2009 for the comparison. The population identification results from DNA analysis from 2007 to 2009 were compared to known identifications from CWTs for 215 chinook salmon. Additionally, we evaluated accuracy of the estimated stock composition for a sample of 133 coded-wire-tagged Cowichan River juveniles captured and sampled during 2007-2009.

Strait of Georgia sea surface temperature (SST, ${ }^{\circ} \mathrm{C}$ ) and salinity (SSS, ppm) were obtained from the Ocean Science webpage maintained at the Institute of Ocean Sciences in Sidney, British Columbia (http://www.pac. dfo-mpo.gc.ca.science/oceans/data-donnees/lighthousesphares.index-eng.html). Data are collected daily at lighthouse stations throughout the Strait of Georgia and monthly averages are posted on the webpage. To obtain monthly values for the entire Strait of Georgia, we averaged the data from 1960 to present from the following stations: Cape Mudge (19601985), Chrome Island, Departure Bay, Entrance Island, Sisters Island, and from West Vancouver (1980-1985). Cape Mudge and West Vancouver stations were closed in 1985.

The Cowichan River flows from Cowichan Lake about $50 \mathrm{~km}$ from Cowichan Bay in the Strait of Georgia (Fig. 7b). A fishway at a partial obstruction allows the passage of adult chinook salmon into Cowichan Lake, although most spawning occurs in the river. Fall spawning chinook salmon return to the river from mid August through to October, and in some years until November. Coho and chum salmon also spawn in the river. The hatchery is about $2 \mathrm{~km}$ from the estuary, however, the juvenile chinook salmon were transported to a release location about 25-30 km from the estuary. A small number were held in seapens and released into the estuary in late May and early July.

\section{Results}

DNA analysis

The population identification results from DNA analysis from 2007 to 2009 were compared to known identifications from CWTs for 215 chinook salmon. The results from both the DNA analysis and the CWT identification were grouped into the following eight common stock areas: Upper Fraser River, Lower Fraser Rivere, South Thompson River, North Thompson River, East Coast Vancouver Island, West Strait of Georgia, Puget Sound, and Columbia River. Of the 215 fish identified using DNA analysis, 204 (95\%) came from the same stock area as the CWT. Seven of the 11 fish that had disagreement between the CWT identification and the DNA stock allocation were fish that were either identified from CWTs as fish from East Coast Vancouver Island but allocated to Puget Sound from DNA analysis, or fish that were identified from CWTs as Puget Sound fish but allocated to East Coast Vancouver Island from DNA analysis.

The stock composition of a sample of 133-CWT Cowichan River individuals estimated with a 280population baseline (Cowichan River was one population in the baseline) was estimated at $98 \%$ Cowichan River origin. On an individual level, all but one of the 133 individuals examined were assigned to Cowichan River origin, with individual probability levels ranging from 0.71 to 1.00 . We concluded that accurate identification of the Cowichan River component of the catch of juvenile chinook salmon was achieved.

Juvenile Pacific salmon surveys

The purse seine survey in the Gulf Islands in late June 2008 captured 186 juvenile chinook salmon throughout the Gulf Islands. The largest catches of 61 chinook salmon occurred within Cowichan Bay. DNA analysis indicated that all except one of the 61 fish were from the Cowichan River and CWTs indicated that 25 or $41 \%$ were from the hatchery. The sample of 115 chinook salmon from all other areas consisted of $75.7 \%$ Cowichan River chinook salmon of which $30.5 \%$ were from the hatchery (Table 1). A preliminary trawl survey on June 24-26 caught 47 chinook salmon in 24 sets throughout the Gulf Islands (Table 1). Only 12 fish were from the 


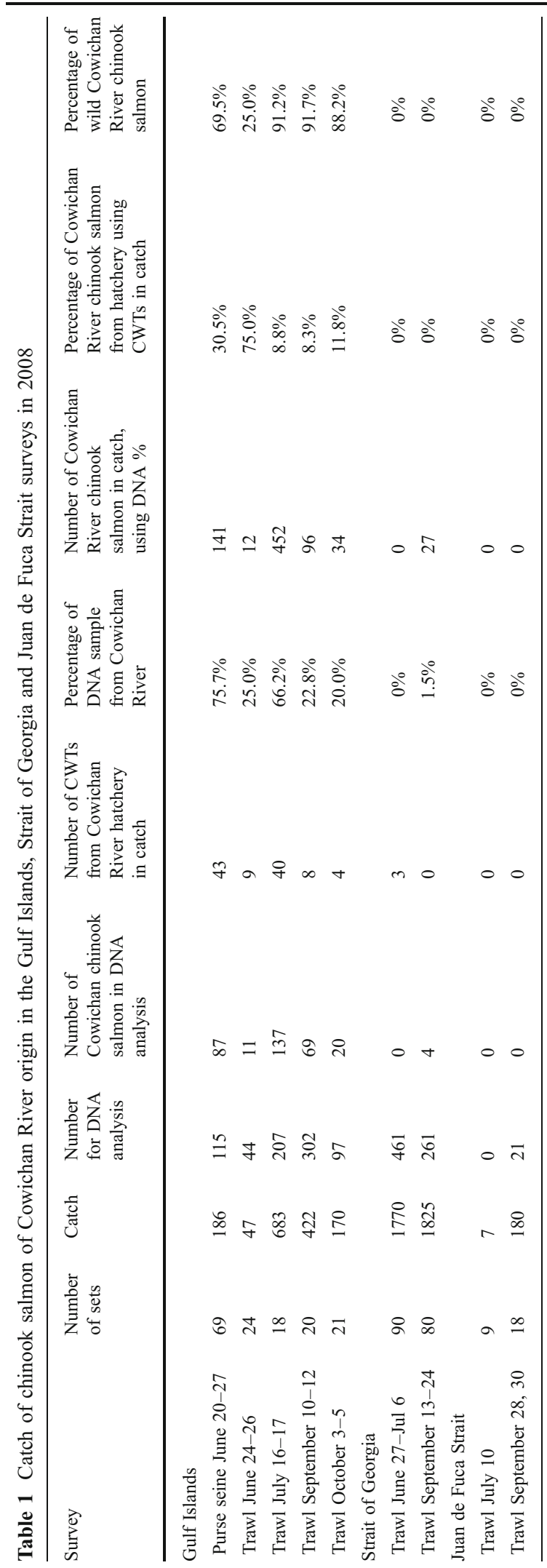

Cowichan River, and $75.0 \%$ (9 of 12) of these were from the hatchery. The mid-July 2008 trawl survey was about three weeks later than the June surveys and had the largest catches of juvenile chinook salmon of all Gulf Island surveys in 2008 (Table 1). Chinook salmon from the Cowichan River comprised $66.2 \%$ of the catch, or 452 fish. We recovered 40 juveniles with a CWT from the Cowichan hatchery which indicates that the percentage of Cowichan hatchery fish in July was $8.8 \%$. Catches declined in the mid September and early October trawl surveys, but the percentage of hatchery fish from the Cowichan River remained about the same at $8.3 \%$ and $11.8 \%$, in September and October, respectively (Table 1). In the mid-July trawl survey, most juvenile chinook salmon were captured in the top $30 \mathrm{~m}$ (Table 2). In September, catches in the depth stratum from $30 \mathrm{~m}$ to $44 \mathrm{~m}$ (head rope depth of $30 \mathrm{~m}$ ) increased slightly (Table 2). However, by early October, juvenile chinook salmon were more evenly distributed within the top $44 \mathrm{~m}$ (Table 2).

The beach seine study from April 8 to June 6 captured 579 juvenile chinook salmon over 11 days of sampling. Wild chinook salmon were captured in each day while hatchery chinook salmon were captured for several days immediately after their release from the hatchery (Table 3). Over the 2 months of beach seining, hatchery fish represented $45 \%$ of the catch of all juvenile chinook salmon. Hatchery fish were consistently larger than the wild fish (Table 4). In mid July, the average lengths of

Table 2 Catches, catch per unit effort (CPUE) for each depth stratum for the trawl survey, 2008

\begin{tabular}{lll}
\hline Date Depth & $\begin{array}{l}\text { Number Catch CPUE } \\
\text { of sets }\end{array}$ \\
\hline
\end{tabular}

\begin{tabular}{lllll}
\hline June 24-26 & $0-14 \mathrm{~m}$ & 15 & 42 & 5.6 \\
& $15-29 \mathrm{~m}$ & 6 & 5 & 1.5 \\
July 16-17 & $30-44 \mathrm{~m}$ & 3 & 0 & 0 \\
& $0-14 \mathrm{~m}$ & 14 & 547 & 78.1 \\
& $15-29 \mathrm{~m}$ & 3 & 130 & 91.8 \\
September 10-12 & $0-14 \mathrm{~m}$ & 10 & 300 & 59.6 \\
& $15-29 \mathrm{~m}$ & 7 & 96 & 27.4 \\
October 3-5 & $30-44 \mathrm{~m}$ & 3 & 26 & 17.3 \\
& $0-14 \mathrm{~m}$ & 9 & 62 & 13.9 \\
& $15-29 \mathrm{~m}$ & 9 & 73 & 16.5 \\
& $30-44 \mathrm{~m}$ & 3 & 35 & 24.7 \\
\hline
\end{tabular}


Table 3 Catches of hatchery and wild juvenile chinook salmon from the Cowichan River in the beach seine study in 2008

\begin{tabular}{lllll}
\hline Date & $\begin{array}{l}\text { Number } \\
\text { of sets }\end{array}$ & $\begin{array}{l}\text { Number of } \\
\text { hatchery fish }\end{array}$ & $\begin{array}{l}\text { Percentage of } \\
\text { hatchery fish }\end{array}$ & $\begin{array}{l}\text { Number of } \\
\text { wild fish }\end{array}$ \\
\hline April 8 & 7 & 0 & $0 \%$ & 1 \\
April 18 & 4 & 0 & $0 \%$ & 5 \\
May 6 & 10 & 9 & $90 \%$ & 1 \\
May 8 & 9 & 10 & $77 \%$ & 3 \\
May 13 & 6 & 2 & $67 \%$ & 1 \\
May 15 & 7 & 0 & $0 \%$ & 2 \\
May 20 & 8 & 0 & $0 \%$ & 3 \\
May 22 & 8 & 5 & $71 \%$ & 2 \\
May 27 & 7 & 8 & $67 \%$ & 4 \\
May 29 & 8 & 0 & $0 \%$ & 30 \\
June 6 & 11 & 225 & $46 \%$ & 268 \\
Total & & 259 & $45 \%$ & 320 \\
\hline
\end{tabular}

April 25, hatchery released 204000 smolts

May 22, hatchery released 230400 smolts

June 2, hatchery released 25300 smolts

hatchery and wild fish had increased by $58 \mathrm{~mm}$ and $19 \mathrm{~mm}$, respectively. Hatchery fish continued to be larger than wild fish in all the samples, although the catch of hatchery fish from the Cowichan hatchery was small (Table 1).

The preliminary trawl survey captured very few chinook salmon, indicating that most juveniles were still in the nearshore areas. Therefore, we combined the two late June surveys to get an estimate of the hatchery and wild percentages in the catch. The estimated percentage of hatchery fish, weighted for the differences in the catches, was $36.1 \%$. The weighted estimate of $36.1 \%$ hatchery fish was used to estimate the number of wild smolts that were produced in the Cowichan River in 2007-2008. The hatchery released 460000 chinook salmon smolts in 2008. If these fish represented $36.1 \%$ of all Cowichan
River chinook salmon, there would be 814200 wild chinook salmon smolts. Another estimate of wild smolt production was made using the reported escapement of 1860 adults, a sex ratio of $50 \%$ males and females, an average fecundity of 3700 eggs and an egg-to-smolt survival of 6\% (Bradford 1995, Tompkins et al. 2005). This calculation produced an estimate of 206500 wild smolts. A third estimate of wild smolt abundance was made using the hatchery percentage of $45 \%$ in the beach seine study. If hatchery and wild chinook salmon smolts had a similar mortality during the beach seine study, there would have been 562200 wild smolts produced.

The abundance estimates (Table 5) can be used to estimate the early marine survival of the hatchery and wild fish. Estimates of wild juvenile chinook salmon survival are a range produced using the three estimates of wild smolt production. The early marine survival of hatchery fish from ocean entry to mid July, mid September and early October were 6.9\%, 1.3\% and $0.8 \%$, respectively (Table 5 ). Wild fish had a $28.2 \%-158.5 \%, 7.8 \%-31.5 \%$ and $3.6 \%-14.3 \%$ survival from ocean entry to mid July, mid September and early October, respectively.

The extensive surveys in the Strait of Georgia in July (Fig. 7) captured larger numbers of juvenile chinook salmon than in the Gulf Islands (Table 1). Samples used for the DNA analysis were distributed throughout the Strait of Georgia (Fig. 8). None of the 461 fish analyzed for DNA came from the Cowichan River, however, there were three fish with a CWT from the Cowichan hatchery that were captured in the Strait of Georgia near a pass leading to the Gulf Islands area. Similar large catches of juvenile chinook salmon were obtained in the September trawl survey. Four $(1.7 \%)$ wild chinook salmon from the Cowichan River were captured (Table 1). Neither of the two surveys in Juan de Fuca Strait in July or September captured any wild or hatchery chinook salmon from
Table 4 Mean length $( \pm$ SD) of hatchery and wild juvenile chinook salmon from the Cowichan River in the Gulf Islands area of the Strait of Georgia in 2008

\begin{tabular}{llcllll}
\hline Date & \multicolumn{1}{l}{ Hatchery } & & \multicolumn{2}{l}{ Wild } \\
\cline { 2 - 3 } \cline { 6 - 7 } & Method & Length (mm) \pm SD & Number & & Length (mm) \pm SD & Number \\
\hline May 22-29 & Beach seine & $96 \pm 5.3$ & 13 & & $67 \pm 10.2$ & 36 \\
July 10-12 & Trawl & $148 \pm 21.8$ & 14 & & $94 \pm 18.5$ & 94 \\
September 10-12 & Trawl & $227 \pm 13.2$ & 7 & & $162 \pm 27.4$ & 63 \\
October 3-4 & Trawl & $282 \pm 35.8$ & 3 & & $205 \pm 17.7$ & 17 \\
\hline
\end{tabular}


Table 5 Abundance estimates from the trawl survey, and the number and percentage of hatchery and wild chinook salmon

\begin{tabular}{|c|c|c|c|c|c|c|c|c|}
\hline \multirow[t]{2}{*}{ Date } & \multirow[t]{2}{*}{ Abundance \pm 2 SD } & \multirow{2}{*}{$\begin{array}{l}\text { Number of } \\
\text { Cowichan River } \\
\text { chinook salmon }\end{array}$} & \multirow{2}{*}{$\begin{array}{l}\text { Number } \\
\text { of wild } \\
\text { fish }\end{array}$} & \multirow{2}{*}{$\begin{array}{l}\text { Number of } \\
\text { hatchery } \\
\text { fish }\end{array}$} & \multirow{2}{*}{$\begin{array}{l}\text { Early marine } \\
\text { survival of } \\
\text { hatchery fish }\end{array}$} & \multicolumn{3}{|c|}{ Early marine survival of wild fish } \\
\hline & & & & & & $\begin{array}{l}\text { Abundance } \\
206500\end{array}$ & $\begin{array}{l}\text { Abundance } \\
562200\end{array}$ & $\begin{array}{l}\text { Abundance } \\
814200\end{array}$ \\
\hline July $16-17$ & $542300 \pm 230800$ & 359000 & 327400 & 31600 & $6.9 \%$ & $158.5 \%$ & $58.2 \%$ & $28.2 \%$ \\
\hline September $10-12$ & $311300 \pm 132400$ & 71000 & 65100 & 5900 & $1.3 \%$ & $31.5 \%$ & $11.6 \%$ & $7.8 \%$ \\
\hline October 3-5 & $166900 \pm 75900$ & 33400 & 29500 & 3900 & $0.8 \%$ & $14.3 \%$ & $5.2 \%$ & $3.6 \%$ \\
\hline
\end{tabular}

the Cowichan River, as indicated from the CWTs and from a sample of DNA (Table 1).

Hatchery fish were released with different codes for the CWTs. The tagged fish were recovered in the various surveys in the Gulf Islands from June to November 2008. Fewer fish were recovered from the April 25 release than the May 29 release in the river (Fig. 9). The rate of recapture varied among tag codes with the most consistent rate occurring for the May 29 release. No recaptures were made for the May 29 release from the sea pen. Recapture rates for the July 2 release from a sea pen ranged from the highest to lowest (Fig. 9). There were 204000 fish released into the river in April 2008 and 18 CWTs were recovered in all surveys. There were 205000 fish released into the river in May 2008 and 68 CWTs were recovered. The rate of recapture of CWTs from the May 29 release was 3.8 times larger than from the April 25 release.

Spring (April to June) sea surface temperatures in the Strait of Georgia demonstrated a clear warming trend since 1960 of approximately $0.28^{\circ} \mathrm{C} /$ decade (Fig. 2a). Winter (December to March) sea surface temperatures showed a similar albeit slightly lower trend of about $0.16^{\circ} \mathrm{C} /$ decade (Fig. 2b). Summer (June to August) sea surface temperatures showed an even steeper increase in warming, averaging $0.39^{\circ} \mathrm{C} /$ decade since 1960 , with average summer SSTs now exceeding $17^{\circ} \mathrm{C}$. Within the long-term trend, there were periods of cooling such as in the 1960 s and early 1970 s or from 2005 to 2008 , but the general trend has been an increase of about $1{ }^{\circ} \mathrm{C}$ over the past 50 years.

\section{Discussion}

The DNA analysis and all surveys indicated that most juvenile hatchery and wild chinook salmon from the Cowichan River remained within the Gulf Islands until at least the end of the survey in September. We are confident that our identifications of hatchery fish were correct because all hatchery fish were tagged
Fig. 8 The samples analyzed for DNA in the Strait of Georgia in the 2008 June 27 to July 6 trawl survey showing that samples were distributed throughout the Strait of Georgia

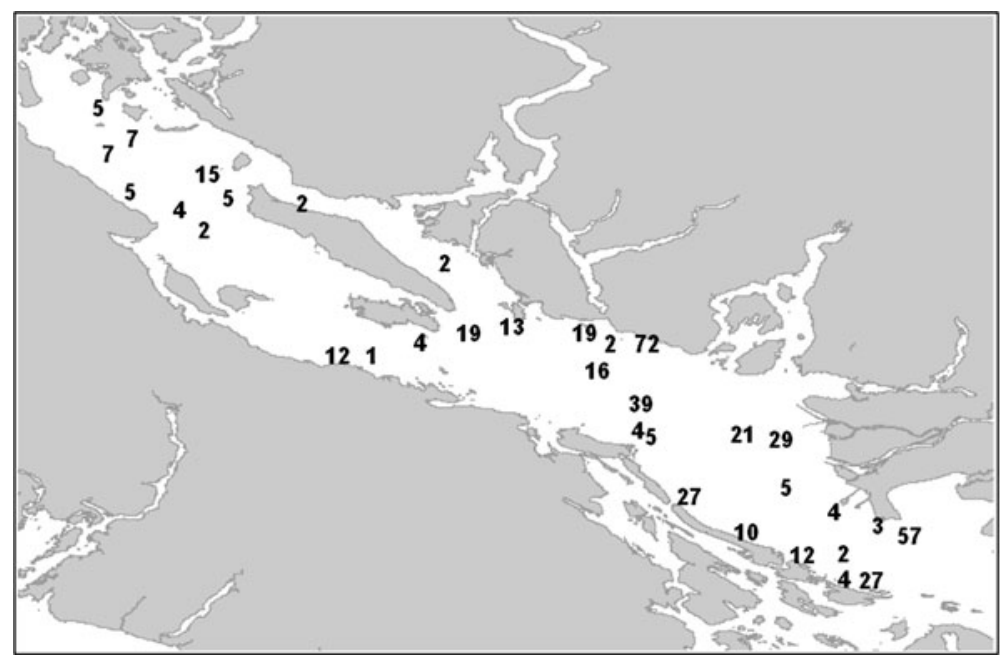




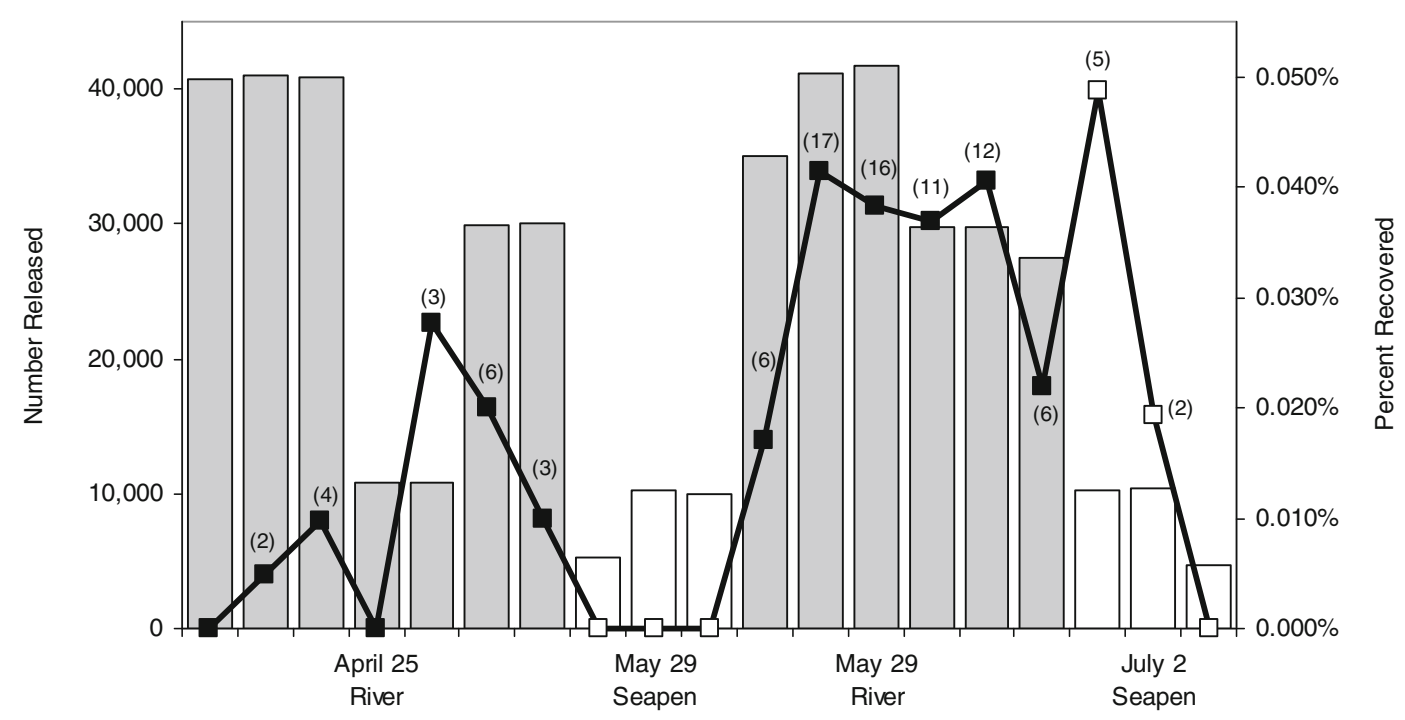

Fig. 9 The number of fish released (bars) and the percentage of CWTs recovered (black line) for each group of fish produced by the Cowichan River Hatchery in 2008. The number of CWTs recovered is shown in brackets. Each group of fish (bars) had a unique tag code

with a CWT. We are also confident that the DNA analysis was reliable as the DNA results were similar to $95 \%-98 \%$ of the CWTs from a number of different stocks, including a sample of 133 CWT fish from the Cowichan River. During this period, the percentage of hatchery fish that survived declined to an estimated $1.3 \%$ in mid September and $0.8 \%$ in early October. There were three Cowichan hatchery fish captured in the standard survey in July in the Strait of Georgia near the Gulf Islands. This indicates that some Cowichan hatchery fish were leaving the survey area in July. However, catches of juvenile hatchery and wild chinook salmon from the Cowichan River were rare outside of the Gulf Islands area as indicated by the DNA analysis. Even if the abundances outside of the Gulf Islands were equal to the abundances in our surveys within the Gulf Islands, the estimated marine survival of the hatchery fish through to the fall would only be about two percent. The recovery of CWTs in the surveys within the Gulf Islands showed that the highest mortalities were for the early releases from the hatchery. It is most likely that these mortalities occurred soon after ocean entry and within the area of the Gulf Islands close to the Cowichan estuary. The very poor early marine survival indicates that most of the marine mortality that affects the brood year strength of the Cowichan River hatchery chinook salmon occurred within the Gulf Islands and within about 5 months of ocean residence.
Not all fish released from the hatchery into the river will survive to enter the ocean, thus the estimated marine mortality includes some freshwater mortality. Perhaps, the most important error in the estimate of early marine survival of hatchery fish is our estimate of abundance. The confidence limits are large and we use a catchability of 1.0 which assumes that all fish in front of the net opening are caught. A true catchability is probably lower, which would increase the abundance and the marine survival. However, despite the imprecision of some estimates, it was clear that very few hatchery fish survived through to early October. This interpretation is supported by an acoustic tagging study in the Gulf Islands in mid July 2008 (Neville et al. 2010). In the acoustic tagging study 70 juvenile chinook salmon were tagged and approximately 63 were hatchery and wild chinook salmon from the Cowichan River. Only one fish of the 70 (from the Big Qualicum hatchery) was detected leaving the Strait of Georgia and this was through Juan de Fuca Strait. The battery life of the acoustic tag was approximately 4 months which would last until at least mid November. The conclusion of the acoustic tagging study was none of the Cowichan River fish were detected after they were tagged and they probably died within the Strait of Georgia.

Estimates of the early marine mortality of the wild chinook salmon juveniles were more problematic. We 
had three estimates of wild smolt abundance that ranged from 814200 to 206500 . The estimate of 814 200 was a simple calculation that assumed that hatchery and wild fish entered the ocean at the same time and had the same mortality up to the time that the hatchery percentages were measured in late June. Our estimate of hatchery percentage from the beach seine survey was $45 \%$, indicating that there were slightly more wild smolts in the ocean than hatchery smolts. However, there were two release periods of hatchery fish in the river on April 25 and May 29 and two releases from a net pen in the ocean on May 29 and July 2. The higher mortalities associated with the earlier releases, as identified by the reduced recapture rate of CWTs, would indicate that it is unlikely that hatchery and wild juveniles had an equal mortality prior to the June surveys. Thus, the estimate of 728 600 wild juveniles would be too large. Also, considering that the escapement-fecundity estimate is about $3 \frac{1}{2}$ times smaller, it is most likely that the larger estimate of wild smolt production is high. The beach seine based estimate of 562200 may be a more accurate estimate of wild smolt production, although it may also be too large. An important observation, however, is that all smaller estimates of wild smolt production increase the survival estimates of wild chinook salmon which increases the difference in the early marine survival between wild and hatchery chinook salmon. If we use the larger estimate of wild juvenile chinook salmon abundance, the survival of wild Cowichan chinook salmon was estimated to be $3.6 \%$ to early October or four times larger than the hatchery survival. If the lower estimate of wild smolt abundance is used, the early marine wild smolt survival is 18 times larger than the hatchery survival through to early October. The intermediate estimate of wild smolt abundance indicates that wild smolt early marine survival is about 6.5 times larger than for hatchery fish. The trawl study in early October resulted in a total catch that was about $50 \%$ smaller than observed 3 weeks earlier. The fish were also deeper in the water column, indicating a change in behaviour had occurred. There were no comprehensive surveys after this date, so it was not possible to identify movements out of the Gulf Islands area. It is probable that the reduced catch and the changes in the percentage of wild chinook salmon were influenced by movements out of the study area in the Gulf Islands. Thus, the estimates of juvenile chinook salmon survival in early October may be low because fish were starting to migrate out of the Gulf Islands. If we compare the survival estimates of hatchery and wild chinook salmon using the September survey, the wild survival is between six, nine and 24 times larger than the hatchery survival, depending on the number of wild smolts. The September samples may provide a better comparison of the early marine survival of the two rearing types, with wild juvenile chinook salmon surviving between six and 24 times better than hatchery-released juveniles.

There were no Cowichan CWTs recovered in the September survey in the Strait of Georgia. There were, however, four wild Cowichan juvenile chinook salmon identified in the DNA sample. This indicates that there was some movement out of the Gulf Islands, but the catches were rare. Any abundance outside of the Gulf Islands would increase the estimate of survival which would increase the difference in survival between hatchery and wild fish.

The errors associated with the estimates of early marine survival of wild chinook salmon are similar to the errors associated with the estimates for hatchery fish. Additionally, there was a substantial error in the estimate of the numbers of wild smolts entering the ocean. The estimate of a hatchery percentage of $45 \%$ in the beach seine survey may be closer to the true percentage. The true early marine survival of juvenile wild chinook salmon from the Cowichan River in the Gulf is not clear; however, it is clear that the estimate is substantially larger than for hatchery fish. The differences in early marine survival between hatchery and wild fish should be a clear indicator that the wild fish are better adapted to survive in the ecosystem within the Gulf Islands.

A number of studies (Bilton et al. 1982; Bilton 1984; Ward and Slaney 1988; Martin and Wertheimer 1989; Ward et al. 1989; Henderson and Cass 1991; Beckman et al. 1998; Friedland et al. 2009) have shown that larger juvenile Pacific salmon survive better in the early marine environment than smaller individuals. Throughout our study, hatchery fish were consistently larger than the better surviving wild chinook salmon. The large mortality of hatchery fish that occurred from ocean entry until mid September would result from some kind of selection from the agent or agents causing the mortality. If the agent was a predator, there was some quality that made the hatchery fish more accessible. It would seem reasonable 
that future hatchery related research should focus on identifying the attributes that result in hatchery fish having the very large early marine mortalities and being more susceptible to the sources of mortalities than the wild fish.

Hatcheries around the Strait of Georgia achieve an average egg-to-smolt production of $70-80 \%$ (MacKinlay et al. 2010) compared to about 6\% for wild chinook salmon (Bradford 1995). This is approximately $12-13$ times better than observed for wild chinook salmon. However, if the hatchery fish have between a six and 24 times greater early marine mortality as found using the September survey data, there may be little value in removing the wild fish from the naturally spawning population. This conclusion is not a criticism of hatcheries; rather it is meant to identify the need to be more experimental. Experimentation is not limited to size and time of release studies, as it is necessary to understand why wild fish can survive better in the early days in the ocean. The importance of the first few months in determining the recruitment of Pacific and Atlantic salmon is well recognized (Parker 1962; Ricker 1976; Pearcy 1992; Hansen and Quinn 1998; Friedland et al. 2009). It is also known that hatchery-reared salmon do not survive as well as their wild counterparts (Cross et al. 1991; Jonsson et al. 1991). These differences in survival may indicate that there were ecological differences between the hatchery and wild fish, as observed in other studies (Beauchamp 2009; Buhle et al. 2009).

We propose that the declining production of Cowichan chinook salmon stocks and possibly all of the declining chinook salmon stocks is a consequence of a changing environment in the early marine period, as others have reported (Coronado and Hilborn 1998). Temperature is correlated with Pacific salmon survival (Mueter et al. 2002; Hinke et al. 2005; Beauchamp 2009) and the temperature in the Strait of Georgia has been increasing. The mechanisms linking temperature to the decreasing marine survivals remain to be identified, but the existing temperatures could be considered stressful for chinook salmon (Hinke et al. 2005; Beauchamp 2009). The declines in the marine survival of chinook salmon are similar to the declines observed for coho salmon in the Strait of Georgia indicating that large-scale ecosystem changes probably are occurring possibly as a consequence of the increasing trend in temperature (Beamish et al. 2008, 2010). Thus, we propose that the general warming of the surface waters is an indicator that juvenile Pacific salmon will continue to be under increasing stress as the temperatures approach critical values (Beauchamp 2009). It appears reasonable to assume that the trend in warming in the next 50 years will be similar or greater that the past 50 years. This would mean that the environment within the Gulf Islands will become even more stressful for the juvenile chinook salmon. In the 1970s it was believed that there was capacity within the ocean to produce more salmon if more juveniles were added. Most scientists today believe that the challenge in the future is to manage Pacific salmon so they can adapt to a more stressful ocean environment. Thus, the future objectives of hatchery programs may be to produce fish that are able to survive in changing ocean environments.

The recent studies of Volk et al. (2010) showed that chinook salmon from the Salmon River had a series of life history types that were characterized by a diversity of estuarine entry times, sizes and periods of nearshore residency. It is possible that this variation in the use of the early marine environment provides the resiliency needed to adapt to a more variable environment as the ocean warms. It is known that chinook salmon have a wide plasticity in smolting behaviour, with sizes ranging from $1 \mathrm{~g}$ to $30 \mathrm{~g}$ and ages from 30 days to 14 months post emergence (Healey 1991; Beckman et al. 2003). Thus, it is possible to consider that the population structure in fresh water is an evolution of adaptation to conditions in the ocean in the immediate area of the ocean adjacent to the river. The concern is that as the Strait of Georgia continues to warm, it may be the evolved resiliency of the wild fish that are best able to adapt to the variability associated with the changing nearshore environment.

Our message is not to encourage the shutting down of hatcheries, but to encourage everyone to recognize the complexities of managing populations of chinook salmon and all populations of Pacific salmon in a changing environment. Continuing to do what we are doing and hoping that the next year will be better makes little sense. We think that the Cowichan River chinook population provides a perfect opportunity to identify exactly what has caused the declining trend and exactly why wild chinook salmon survive better than hatchery chinook salmon. This information will make better use of hatcheries and show British 
Columbians how their impacts on climate are affecting both wild and hatchery Pacific salmon.

Acknowledgments We thank the Pacific Salmon Commission for funding this study and Paul Rickard and Wilf Luedke for their advice and support. Kim Jonsen conducted the DNA analysis and John Candy managed the data analysis for the chinook salmon samples at the Micro Genetics Laboratory at the Pacific Biological Station. Lana Fitzpatrick assisted with field work, figures and manuscript preparation.

Open Access This article is distributed under the terms of the Creative Commons Attribution Noncommercial License which permits any noncommercial use, distribution, and reproduction in any medium, provided the original author(s) and source are credited.

\section{References}

Beacham TD, Candy JR, Jonsen KL, Supernault J, Wetklo M, Deng L, Miller KM, Withler RE (2006) Estimation of stock composition and individual identification of Chinook salmon across the Pacific Rim basis using microsatellite variation. Trans Am Fish Soc 135:861-888

Beamish RJ, Neville C-EM (1999) Large-scale climate-related changes in the carrying capacity of salmon in the Strait of Georgia and northern North Pacific ecosystems. In: Sherman K, Tang Q (eds) Large marine ecosystems of the Pacific Rim. Blackwell Science, Malden, pp 27-41

Beamish RJ, Riddell BE, Neville C-EM, Thomson BL, Zhang ZY (1995) Declines in chinook salmon catches in the Strait of Georgia in relation to shifts in the marine environment. Fish Oceanogr 4:243-256

Beamish RJ, McCaughran D, King JR, Sweeting RM, McFarlane GA (2000) Estimating the abundance of juvenile coho salmon in the Strait of Georgia by means of surface trawls. N Am J Fish Manage 20:369-375

Beamish RJ, Sweeting RM, Neville CM, Lange K (2007) Ocean changes in the Strait of Georgia indicate a need to link hatchery programs, fishing strategies and early marine studies of ocean carrying capacity into an ecosystem approach to manage coho salmon. Extended abstract NPAFC Tech Rep 7:49-51

Beamish RJ, Sweeting RM, Lange KL, Neville CM (2008) Changing trends in the population ecology of hatchery and wild coho salmon in the Strait of Georgia. Trans Am Fish Soc 137:503-520

Beamish RJ, Sweeting RM, Lange KL, Noakes DJ, Preikshot D, Neville CM (2010) Early marine survival of coho salmon in the Strait of Georgia declines to very low levels. Mar Coast Fish 2:424-439

Beauchamp DA (2009) Bioenergetic ontogeny: Linking climate and mass-specific feeding to life-cycle growth and survival of salmon. Am Fish Soc Symp 70:1-19

Beckman BR, Larsen DA, Lee-Pawlik B, Dickhoff WW (1998) Relation of fish size and growth rate to migration of spring chinook salmon smolts. N Am J Fish Manage 18:537-546
Beckman BR, Larsen DA, Dickhoff WW (2003) Life history plasticity in chinook salmon: relation of size and growth rate to autumnal smolting. Aquaculture 222:149-165

Bilton HT (1984) Returns of chinook salmon in relation to juvenile size at release. Can Tech Rep Fish Aquat Sci 1245

Bilton HT, Alderdice DF, Schnute JT (1982) Influence of time and size at release of juvenile coho salmon (Oncorhynchus kisutch) on returns at maturity. Can J Fish Aquat Sci 39:426-447

Bradford MJ (1995) Comparative review of Pacific salmon survival rates. Can J Fish Aquat Sci 52:1327-1338

Buhle ER, Holsman KK, Scheuerell MD, Albaugh A (2009) Using an unplanned experiment to evaluate the effects of hatcheries and environmental variation on threatened populations of wild salmon. Biol Conserv 142:2449-2455

Coronado C, Hilborn R (1998) Spatial and temporal factors affecting survival in coho and fall chinook salmon in the Pacific Northwest. Bull Mar Sci 62:409-425

Cross CL, Lapi L, Perry EA (1991) Production of Chinook and coho salmon from British Columbia hatcheries, 1971 through 1989. Can Tech Rep Fish Aquat Sci 1816:48p

Fisheries and Environment Canada (1978) The salmonid enhancement program. A public discussion paper. Information Branch. Fisheries and Marine Science Service, Vancouver

Friedland KD, Moore D, Hogan F (2009) Rtrospective growth analysis of Atlantic salmon (Salmo salar) from the Miramichi River, Canada. Can J Fish Aquat Sci 66:12941308

Hansen LP, Quinn TP (1998) The marine phase of the Atlantic salmon (Salmo salar) life cycle, with comparisons to Pacific salmon. Can J Fish Aquat Sci 55(Supp. 1):104118

Healey MC (1991) Life history of chinook salmon. In: Groot C, Margolis L (eds) Pacific salmon life histories. University of British Columbia Press, Vancouver, pp 311-393

Henderson MA, Cass AJ (1991) Effect of smolt size on smolt-toadult survival for Chilko Lake sockeye salmn (Oncorhynchus nerka). Can J Fish Aquat Sci 48:988-994

Hinke JR, Watters GM, Boehlert GW, Zedonis P (2005) Ocean habitat use in autumn by chinook salmon in coastal waters of Oregon and California. Mar Ecol Prog Ser 285:181-192

Jonsson B, Jonsson N, Hansen LP (1991) Difference in life history and migratory behaviour between wild and hatchery reared Atlantic salmon in nature. Aquaculture 98:69-78

MacKinlay D, Lehman S, Bateman J, Cook R (2010) Pacific Salmon Hatcheries in British Columbia. Report to the Salmon Enhancement and Habitat Advisory Board. Available at www.sehab.org/pdf/hatcheries

Martin RM, Wertheimer A (1989) Adult production of chinook salmon reared at different densities and released as two smolt sizes. Prog Fish Culturist 51:194-200

Mueter FJ, Ware DM, Peterman RM (2002) Spatial correlation patterns in coastal environmental variables and survival rates of Pacific salmon in the Northeast Pacific Ocean. Fish Oceanogr 11:205-218

Neaves PI, Wallace CG, Candy JR, Beacham TD (2005) CBayes: Computer program for mixed stock analysis of allelic data. Version v4.02. Free program distributed by the 
authors over the internet from http://www.pac.dfo-mpo.gc. $\mathrm{ca} / \mathrm{sci} / \mathrm{mgl} /$ Cbayes_e.htm

Neville CM, Beamish RJ, Chittenden CM (2010) The use of acoustic tags to monitor the movement and survival of juvenile chinook salmon in the Strait of Georgia. N Pac Anadromous Fish Comm Document 1286:19

Pacific Salmon Commission (PSC) (1987) Pacific Salmon Commission Chinook Technical Committee Report. 1986 Summary Report TCChinook 8704, 43 p.

Parken CK, McNicol RE, Irvine JR (2006) Habitat-based methods to estimate escapement goals for data limited Chinook salmon stocks in British Columbia. Canadian Science Advisory Secretariat Research Document 2006/ 083, p. 74

Parker RR (1962) Estimations of ocean mortality rates for Pacific salmon (Oncorhynchus). J Fish Res Board Can 19:561-589

Pearcy WG (1992) Ocean Ecology of North Pacific Salmonids. University of Washington Press, Washington Sea Grant, 179

Pella J, Masuda M (2001) Bayesian method for analysis of stock mixtures from genetic characters. Fish Bull 99:151-167

Ricker WE (1976) Review of the rate of growth and mortality of Pacific salmon in salt water, and noncatch mortality caused by fishing. J Fish Res Board Can 33:1483-1524

Riddell BE, Nagtegaal DA, Chen D (2000) A biologicallybased escapement goal for Cowichan River Fall Chinook salmon (Oncorhynchus tshawyscha). Pac Sci Advice Rev Committee Working Pap S00-17:30p

Sweeting RM, Beamish RJ, Noakes DJ, Neville CM (2003) Replacement of wild coho salmon by hatchery-reared coho salmon in the Strait of Georgia over the past three decades. N Am J Fish Manage 23:492-502

Thomson RE, Foreman MGG (1998) Basin areas and volumes for coastal southwest British Columbia and northwest Washington. Can Tech Rep Hydrol Ocean Sci 196:17

Tompkins A, Riddell B, Nagtegaal DA (2005) A biologicallybased escapement goal for Cowichan River Fall chinook salmon (Oncorhynchus tshawtyscha). Canadian Science Advisory Secretariat Research Document 2005/095, p. 42.

Volk EC, Bottom DL, Jones KK, Simenstad CA (2010) Reconstructing juvenile Chinook salmon life history in the Salmon River estuary, Oregon, using otolith microchemistry and microstructure. Trans Am Fish Soc 139:535-549

Ward BR, Slaney PA (1988) Life history and smolt-to-adult survival of Keogh River steelhead (Salmo gairdneri) and the relationship to smolt size. Can J Fish Aquat Sci 45:1110-1122

Ward BR, Slaney PA, Facchin AR, Land RW (1989) Size-based survival in steelhead trout: back-calculated lengths from adults' scales compared to migrated smolts at the Keogh River, British Columbia. Can J Fish Aquat Sci 46:1953-1858 